\title{
SELECTIVE CONTROL OF WEEDS IN NEW ZEALAND WETLANDS
}

\author{
P.D. CHAMPION
}

\author{
NIWA, PO Box 11-115, Hamilton
}

\begin{abstract}
Weed invasion is seen as one of the major threats to many of New Zealand's endangered native wetland plants. The herbicides fluazifop, haloxyfop, clethodim, clopyralid, triclopyr, dicamba, dicamba/2,4-D and glyphosate were screened for control of 13 introduced and 17 native wetland plants in a pot trial. Initial assessments of the first three herbicides show good control of target grass weeds with no damage to most native species apart from the grasses. Clopyralid provided control of target broadleaf weed species without damage to many native grasses, sedges, rushes and some broadleaf species. Other treatments gave effective control of target species but generally caused high mortality of native species.
\end{abstract}

Keywords: wetlands, weeds, selective control, rare plants.

\section{INTRODUCTION}

There is a growing awareness that the impacts of weed invasions threaten the viability of many of New Zealand's native species and community types (Williams and Timmins 1990; Owen 1997). In the case of wetlands, this compounds a loss of over $90 \%$ of these areas since 1840 , which has fragmented the wetland habitat. This fragmentation has increased the likelihood of weed access and invasion. Management of weeds in wetlands by herbicides has rarely been attempted, although the relatively non-selective herbicide glyphosate is occasionally used. Selective herbicides have been used for many years for the control of weeds in cropping and pastoral situations in New Zealand, but rarely in natural systems. A successful example of selective control would be the use of haloxyfop to eliminate the estuarine grass Spartina alterniflora from Ohiwa Harbour, Bay of Plenty, without damage to mangroves (Avicennia marina) in the area (Shaw and Gosling 1997).

The marginal wetlands surrounding tarns and lakes throughout much of New Zealand contain a high concentration of endangered native, small, turf-forming species, including the grasses Amphibromus fluitans and tufted hair grass Deschampsia caespitosa, the sedge Isolepis basilaris, the rush Juncus holoshoenus, and the herbaceous dicotyledons Crassula ruamahunga, C. hunua, Acaena rorida, Mazus novaezeelandiae and Iti lacustris (Cameron et al. 1995). Associated native species include the fern Pilularia novae-zelandiae, the sedges Carex gaudichadiana and spike rush Eleocharis acuta, and the herbs Leptinella maniototo, Galium perpusillum, Hypsella rivalis, Gratiola sexdentata and starweed (Plantago triandra).

The small stature of these native species predispose them to be outcompeted by taller, or faster growing wetland weed species, including the grasses Mercer grass (Paspalum distichum), kneed foxtail (Alopecuris geniculatus), creeping bent (Agrostis stolonifera) and Yorkshire fog (Holcus lanatus), oval sedge (Carex ovalis), the rushes bulbous rush (Juncus bulbosus), jointed rush (J. articulatus) and hard rush (J. squarrosus), and the broadleaf dicotyledons water purslane (Ludwigia palustris) and lotus (Lotus pedunculatus). Some weeds of dry land are also problems when they invade ephemeral wetlands during periods of drought; these species include tall fescue (Festuca arundinacea), browntop (Agrostis capillaris) and white clover (Trifolium repens). 
The aim of this investigation was to identify potentially suitable selective herbicides that could control weed species, without damaging the rare and endangered native species threatened by those weeds.

\section{Plants}

\section{MATERIALS AND METHODS}

Wetland weed species were collected from around the Waikato and Westland and propagated at the NIWA Ruakura outdoor experimental facility in Hamilton. A selection of native wetland plants including several species deemed to be in immediate danger of extinction were obtained from existing plant collections or, where necessary, collected from the field (Glenmore Tarnfield near Tekapo, Baker Tarnfield near Lake Coleridge, Lake Wairarapa, and lower Waikato lakes near Huntly), and also cultured at Ruakura.

All species were cultured in potting mix in $75 \mathrm{~mm}$ diameter pots $(100 \mathrm{~mm}$ for tall fescue). Plants were grown in periodically flooded troughs for at least 6 weeks prior to herbicide application.

\section{Herbicide trial}

The herbicides fluazifop, haloxyfop, clethodim, clopyralid, triclopyr, dicamba and dicamba/2,4-D were selected for this trial based on label claims for weeds controlled and previous experience with their selectivity. Glyphosate was also included in the trial for comparative purposes. Rates of herbicides used were based on label rates for each target species, with the addition of a higher $(10.8 \mathrm{mg} /$ litre $)$ and lower ( $1.8 \mathrm{mg} / \mathrm{litre}$ ) rate of glyphosate. The adjuvant Citowett was used with fluazifop, while Uptake was used with haloxyfop and clethodim according to label specifications.

Herbicides were spot-sprayed, using a one litre hand-held sprayer, onto 2-6 pots of each native wetland species and 8-10 pots of target weed species on 3 April 1998. Number of pots used per treatment was dependent on availability of plant material. Conditions were overcast, with light rain 6 hours after the final herbicide application.

Plants were grouped into each treatment and initially assessed for herbicide damage on 1 May 1998. Plants were scored as healthy, damaged (more than $50 \%$ killed), or dead compared to untreated plants.

\section{RESULTS AND DISCUSSION}

Initial evaluations of herbicide damage to weed and native wetland species at representative concentrations of each herbicide are presented in Tables 1 and 2.

The grass specific herbicides fluazifop, haloxyfop and clethodim provided good control of target grass weeds apart from Mercer grass which was only controlled by haloxyfop ( $4 \mathrm{mg} /$ litre $)$ and clethodim $(0.72 \mathrm{mg} /$ litre). The endangered grass A. fluitans was killed by all these treatments, but tufted hair grass was undamaged by fluazifop and clethodim $(0.12 \mathrm{mg} / \mathrm{litre})$ treatments. All other native species tested appeared to be tolerant of these three herbicides apart from G. perpusillum and I. lacustris which were killed by fluazifop and haloxyfop ( $4 \mathrm{mg} /$ litre) and $A$. rorida, which was killed by the haloxyfop (4 mg/litre) treatment.

The broadleaf specific herbicides clopyralid, triclopyr, dicamba and dicamba/2,4D were effective in the control of target weeds, apart from dicamba/2,4-D which was effective on the legumes, water purslane, hard and bulbous rush, but not jointed rush and oval sedge. Of these herbicides clopyralid was the most selective with little or no apparent damage to native sedges, rushes, D. caespitosa, Crassula spp., P. novaezelandiae, G. sexdentata, M. novaezeelandiae and I. lacustris. Trichlopyr did not damage native sedges, rushes and tufted hair grass. Dicamba and dicamba/2,4-D were injurious to most of the species tested.

Glyphosate treatments gave control of weed species apart from the lowest rate of $1.8 \mathrm{mg} /$ litre rate which did not control water purslane. Most native species were killed, or damaged by all rates of this herbicide used in this trial.

Further investigation of haloxyfop, clethodim, clopyralid and triclopyr is warranted for the control of wetland weeds in areas where rare species could be affected. Field trials are planned for 1998/99. 
TABLE 1: Evaluation of untreated and fluazifop, haloxyfop and clethodim treated weeds and native wetland species. Counts relate to number of healthy plants, $d$ indicates damaged plants.

\begin{tabular}{lccccc}
\hline & \multicolumn{5}{c}{ Rate (mg/litre) } \\
Species & Control & fluazifop & haloxyfop & clethodim & clethodim \\
& & 1.88 & 4.00 & 0.72 & 0.12 \\
\hline Weed species & & & & & \\
Agrostis capillaris & $30 / 30$ & $0 / 10$ & $0 / 10$ & -1 & $1 / 10$ \\
Agrostis stolonifera & $30 / 30$ & $2 d / 10$ & $0 / 10$ & - & $3 / 10$ \\
Alopecuris geniculatus & $26 / 26$ & $0 / 10$ & $0 / 10$ & - & $3 / 10$ \\
Festuca arundinacea & $30 / 30$ & - & - & $9 d / 10$ & $10 / 10$ \\
Holcus lanatus & $30 / 30$ & $3 d / 10$ & - & $0 / 10$ & $6 d / 10$ \\
Paspalum distichum & $30 / 30$ & $9 / 10$ & $0 / 10$ & $5 d / 10$ & - \\
& & & & & \\
Native species & & & & & \\
Acaena rorida & $9 / 10$ & $4 / 5$ & $0 / 5$ & $5 / 5$ & $5 / 5$ \\
Amphibromus fluitans & $8 / 10$ & $0 / 4$ & $0 / 4$ & $0 / 4$ & $1 d / 4$ \\
Carex gaudichaudiana & $11 / 11$ & $5 / 5$ & $5 / 5$ & $5 / 5$ & $5 / 5$ \\
Crassula hunua & $10 / 10$ & $4 / 5$ & $5 / 5$ & $5 / 5$ & $5 / 5$ \\
Crassula ruamahanga & $10 / 10$ & $5 / 5$ & $5 / 5$ & $5 / 5$ & $5 / 5$ \\
Deschampsia caespitosa & $8 / 8$ & $4 / 4$ & $2 d / 4$ & $2 d / 4$ & $4 / 4$ \\
Eleocharis acuta & $11 / 11$ & $4 / 4$ & $4 / 4$ & $4 / 4$ & $4 / 4$ \\
Galium perpusillum & $10 / 10$ & $0 / 4$ & $1 / 4$ & $4 / 4$ & $4 / 4$ \\
Gratiola sexdentata & $10 / 10$ & $4 / 4$ & $4 / 4$ & $4 / 4$ & $5 / 5$ \\
Hypsella rivalis & $10 / 10$ & $2 / 3$ & $2 / 3$ & $3 / 3$ & $3 / 3$ \\
Isolepis basilaris & $10 / 10$ & $5 / 5$ & $5 / 5$ & $5 / 5$ & $5 / 5$ \\
Iti lacustris & $8 / 8$ & $2 / 4$ & $0 / 4$ & $4 / 4$ & $4 / 4$ \\
Juncus holoschoenus & $30 / 30$ & $6 / 6$ & $6 / 6$ & $6 / 6$ & $6 / 6$ \\
Leptinella maniototo & $5 / 6$ & $3 / 3$ & - & - & - \\
Mazus novaezeelandiae & $20 / 20$ & $5 / 5$ & $4 / 5$ & $5 / 5$ & $5 / 5$ \\
Pilularia novae-zelandiae & $8 / 9$ & $4 / 4$ & $4 / 4$ & $4 / 4$ & $4 / 4$ \\
Plantago triandra & $7 / 9$ & $3 / 3$ & $3 / 3$ & $3 / 3$ & - \\
\hline - & & & & &
\end{tabular}

$1=$ not tested.

TABLE 2: Evaluation of clopyralid, triclopyr, dicamba and glyphosate treated weeds and native wetland species. Counts relate to healthy plants, $d$ indicates damaged plants.

Species

Rate (mg/litre)

\begin{tabular}{lccccc}
\hline & \multicolumn{5}{c}{ Rate (mg/litre) } \\
Species & clopyralid & triclopyr & dicamba & glyphosate & glyphosate \\
& 1.5 & 6.0 & 4.0 & 5.4 & 3.6 \\
\hline Weed species & & & & & \\
Agrostis capillaris & -1 & - & - & - & $0 / 10$ \\
Agrostis stolonifera & - & - & - & - & $0 / 10$ \\
Alopecuris geniculatus & - & - & - & - & $0 / 10$ \\
Carex ovalis & - & - & - & $0 / 10$ & $0 / 10$ \\
Festuca arundinacea & - & - & - & - & $0 / 10$ \\
Holcus lanatus & - & - & - & - & $0 / 10$ \\
Juncus articulatus & - & - & - & $0 / 10$ & $0 / 10$ \\
Juncus bulbosus & - & - & - & $0 / 8$ & $2 / 8$ \\
Juncus squarrosus & - & - & - & $0 / 10$ & $0 / 10$ \\
Lotus pedunculatus & $0 / 10$ & $0 / 10$ & $0 / 8$ & - & $0 / 10$ \\
Ludwigia palustris & $10 d / 10$ & $0 / 10$ & $0 / 8$ & - & $2 / 10$ \\
\hline
\end{tabular}


Table 2 continued

\begin{tabular}{lccccc}
\hline & \multicolumn{5}{c}{ Rate (mg/litre) } \\
Species & clopyralid & triclopyr & dicamba & glyphosate & glyphosate \\
& 1.5 & 6.0 & 4.0 & 5.4 & 3.6 \\
\hline Paspalum distichum & - & - & - & $0 / 10$ & $0 / 10$ \\
Trifolium repens & $0 / 10$ & $0 / 10$ & $0 / 8$ & - & $0 / 10$ \\
& & & & & \\
Native species & & & & & \\
Acaena rorida & $0 / 4$ & $0 / 5$ & $0 / 5$ & $0 / 5$ & $0 / 5$ \\
Amphibromus fluitans & $0 / 4$ & $1 / 4$ & $0 / 4$ & $0 / 4$ & $0 / 4$ \\
Carex gaudichaudiana & $4 / 4$ & $5 / 5$ & $5 d / 5$ & $0 / 5$ & $0 / 5$ \\
Crassula hunua & $3 / 3$ & $0 / 5$ & $0 / 5$ & $0 / 5$ & $5 d / 5$ \\
Crassula ruamahanga & $5 / 5$ & $0 / 5$ & $5 d / 5$ & $4 d / 5$ & $5 d / 5$ \\
Deschampsia caespitosa & $3 / 3$ & $4 / 4$ & $4 / 4$ & $0 / 4$ & $0 / 4$ \\
Eleocharis acuta & $3 / 3$ & $3 / 3$ & $0 / 4$ & $0 / 4$ & $0 / 4$ \\
Galium perpusillum & $0 / 3$ & $0 / 3$ & $0 / 4$ & $0 / 4$ & $0 / 4$ \\
Gratiola sexdentata & $3 / 4$ & $0 / 5$ & $0 / 4$ & $0 / 5$ & $0 / 5$ \\
Hypsella rivalis & $0 / 3$ & $0 / 3$ & $0 / 3$ & - & $1 / 3$ \\
Isolepis basilaris & $4 / 4$ & $4 d / 5$ & $0 / 5$ & $0 / 5$ & $3 d / 5$ \\
Iti lacustris & $3 d / 3$ & $0 / 4$ & $0 / 4$ & $4 / 4$ & $0 / 4$ \\
Juncus holoschoenus & $5 / 5$ & $5 / 5$ & $6 / 6$ & $6 d / 6$ & $6 d / 6$ \\
Leptinella maniototo & $0 / 3$ & $0 / 3$ & $0 / 2$ & - & - \\
Mazus novaezeelandiae & $3 / 4$ & $0 / 5$ & $1 / 5$ & $0 / 5$ & $0 / 5$ \\
Pilularia novae-zelandiae & $3 / 3$ & $0 / 3$ & $3 / 3$ & $0 / 4$ & - \\
Plantago triandra & $2 d / 3$ & $0 / 3$ & $0 / 3$ & - & $0 / 3$ \\
\hline & & & & &
\end{tabular}

$1=$ not tested.

\section{ACKNOWLEDGEMENTS}

I would like to thank John Clayton, Aleki Taumoepeau, Tricia Warren and Tony Dugdale for assistance with the trial. Andrew Townsend, Trevor James and Margaret Auger all provided valuable comments for the trial design. I am grateful to the Biodiversity Recovery Unit of the Department of Conservation who funded this work and to Dow Elanco (NZ) Ltd. and Nufarm Ltd. who provided some of the herbicides used.

\section{REFERENCES}

Cameron, E.K., deLange, P.J., Given, D.R., Johnson, P.N. and Ogle, C.C., 1995. Threatened and local plant lists (1995 revision). N.Z. Botanical Soc. Newsletter 39: 15-28.

Owen, S.J., 1997. Ecological Weeds on Conservation Land in New Zealand: a Database. Department of Conservation, Wellington, New Zealand.

Shaw, W.B. and Gosling, D.S., 1997. Spartina ecology, control and eradication recent New Zealand experience. Proc. 2nd Internat. Spartina Conf.: 32-38.

Williams, P.A. and Timmins, S.M., 1990. Weeds in New Zealand Protected Natural Areas: a Review for the Department of Conservation. Science and Research Series No. 14, Department of Conservation, Wellington, New Zealand. 